\section{Efektivitas pemberian pisang kepok (Musa paradisiaca formatipyca) dan vitamin B 6 dalam menurunkan intensitas emisis gravidarum pada ibu hamil Effectiveness the giving of Kepok banana (Musa paradisiaca formatipyca) and vitamin B6 in reducing the intensity of emesis gravidarum in pregnant women}

\author{
Ratna Dewi ${ }^{1}$, Rahmi $^{2}$
}

SAGO: Gizi dan Kesehatan 2020, Vol. 1(2) 180-184 (c) The Author(s) 2020

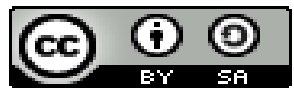

DOI: http://dx.doi.org/10.30867/sago.v1i2.413 https://ejournal.poltekkesaceh.ac.id/index.php/ gikes Poltekkes Kemenkes Aceh

\begin{abstract}
Background: Nausea and vomiting often occur in early pregnancy, usually because pregnant women are lazy to eat so that their intake of nutrients is reduced. Bananas contain vitamin B6 is a water-soluble vitamin. Vitamin B6 can help promote the development of central nervous system cells in the fetus. The daily amount required for pregnant women to meet vitamin B6 is 1.9 milligrams. One medium banana can contain 4 milligrams.

Purpose: This study aims to determine the effect of giving Kepok banana (Musa paradisiaca formatypica) and Vitamin B6 in reducing the intensity of nausea and vomiting in pregnant women.

Method: This study used a Quasi-Experimental design using a pretest-posttest design. The population in this study were pregnant women who experienced nausea and vomiting. The sampling technique used was the purposive sampling technique. Data analysis was performed using the Dependent T-test and the Independent T-test.

Results: The results showed that there was a significant effect of giving Kepok banana and vitamin B6 in reducing the intensity of gravidarum emission in pregnant women $(p=0.000)$. Besides, it was also reported that there was a difference between giving Kepok banana and giving Vitamin B6 related to decreasing the intensity of gravidarum emission in the mother pregnant ( $p$-value $=0.045)$.

Conclusion: The giving of Kepok banana and vitamin $\mathrm{B} 6$ has an effect in reducing the intensity of gravidarum emission in pregnant women, and Kepok banana is more effective against the intensity of gravidarum emission in pregnant women. Suggestions, for pregnant women to treat symptoms of nausea and vomiting, one of which is consuming banana kepok and reducing the use of drugs.
\end{abstract}

\title{
Keywords
}

Kepok banana, nausea and vomiting, pregnant women, vitamin B6

\begin{abstract}
Abstrak
Latar Belakang: Mual muntah sering terjadi pada awal kehamilan, biasanya bawaan ibu hamil malas makan sehingga asupan zat-zat gizi berkurang. Pisang mengandung vitamin B6 adalah vitamin yang larut didalam air. Vitamin B6 dapat membantu meningkatkan pengembangan sel sistem syaraf pusat pada janin. Jumlah harian yang diperlukan ibu hamil untuk memenuhi vitamin B6 adalah 1.9 miligram. Satu pisang ukuran sedang dapat mengandung 4 miligram.

Tujuan: Penelitian bertujuan untuk mengetahui pengaruh pemberian pisang kepok (Musa paradisiaca formatypica) dan Vitamin B6 dalam menurunkan intensitas mual muntah pada ibu hamil.
\end{abstract}

1 Program Studi Kebidanan, Jurusan Kebidanan Politeknik Kesehatan Kemenkes Aceh, Indonesia. E-mail: ratnadewisa@gmail.com

2 Program Studi Kebidanan, Jurusan Kebidanan Politeknik Kesehatan Kemenkes Aceh, Indonesia. E-mail: rahmi.sukardi@yahoo.co.id 
Metode: Penelitian menggunakan desain Quasi-Eksperimen dengan menggunakan rancangan pretest-posttest design. Populasi dalam penelitian ini adalah ibu hamil yang mengalami mual muntah. Teknik pengambilan sampel yaitu menggunakan teknik Purposive Sampling. Analisa data dilakukan dengan menggunakan uji Dependent T-test dan Independent T-test.

Hasil: Hasil penelitian menunjukkan bahwa secara signifikan terdapat pengaruh pemberian pisang kepok dan vitamin B6 dalam menurunkan intensitas emisis gravidarum pada ibu hamil $(p=0.000)$, selain itu dilaporkan juga bahwa terdapat perbedaan antara pemberian pisang kepok dengan pemberian Vitamin B6 terkait penurunan intensitas emisis gravidarum pada ibu hamil (nilai $p=0.045$ ).

Kesimpulan: Pemberian pisang kepok dan vitamin B6 berpengaruh dalam menurunkan intensitas emisis gravidarum pada ibu hamil, dan pisang kepok lebih efektif terhadap intensitas emisis gravidarum pada ibu hamil. Saran, bagi ibu hamil untuk mengobati gejala mual dan muntah salah satunya mengkonsumsi pisang kepok dan mengurangi penggunaan obat-obatan.

Kata kunci

Ibu hamil, mual muntah, pisang kepok, vitamin B6

\section{Pendahuluan}

$\mathrm{M}$ ual muntah merupakan salah satu gejala paling awal, paling umum dan paling menyebabkan stres yang dikaitkan dengan kehamilan. Hampir 50-90\% wanita hamil mengalami mual muntah pada trimester pertama. Mual dan muntah seringkali diabaikan karena dianggap sebagai sebuah konsekuensi diawal kehamilan tanpa mengikuti dampak hebat yang ditimbulkan pada wanita. Dari kebanyakan wanita hamil yang mengalami mual muntah akan mengalami perubahan pada hormon progesteron dan esterogen yang ada dalam tubuh meningkat hal itulah yang menyebabkan mual di pagi hari pada kehamilan trimester pertama. Tetapi frekuensi terjadinya mual muntah tidak hanya di pagi hari melainkan bisa siang bahkan malam hari (Aritonang, 2010).

Mayoritas ibu hamil yang mengalami mual muntah hanya mengerti bahwa mual muntah yang dialami ibu hamil hanya dapat diatasi dengan penggunaan obat, sedangkan penggunaan obatobatan pada ibu hamil sangat berpengaruh pada janin yang sedang dikandung. Untuk mengatasi hal tersebut ibu hamil selain mengkonsumsi obatobatan untuk mengatasi mual muntah, ibu bisa mencoba berbagai buah yang dianjurkan seperti buah kepok yang dapat mengatasi mual (Rohmah et al., 2017).

Pisang merupakan makanan terbaik karena mengandung vitamin yang diperlukan oleh ibu hamil. Selain pisang, makanan yang dapat mengurangi mual muntah pada ibu hamil ialah jahe dan daun mint. Jahe dan daun mint memiliki kandungan B6 yang juga dapat mengurangi keluhan mual muntah pada ibu hamil, namun peneliti mengambil pisang sebab banyak ibu hamil yang suka mengkonsumsi pisang dan pisang juga mudah didapatkan (Siska, 2015).

Penelitian Rini \& Siti (2017), melaporkan bahwa hasil pemeriksaan di laboratorium dengan sediaan menggunakan pisang kepok yang terdiri dari 3 macam bentuk konsumsi pisang kepok, pertama: pisang kepok yang mengkal mengandung vitamin B6 sebesar 0.2022 $\mathrm{mg} / \mathrm{ml}$, kedua: pisang kepok masak mengandung vitamin B6 sebesar $0.2530 \mathrm{mg} / \mathrm{ml}$, dan ketiga: pisang kepok yang direbus selama 40 menit mengandung vitamin B6 sebesar $0.3646 \mathrm{mg} / \mathrm{ml}$. Kandungan vitamin B6 pisang kepok yang di rebus 40 menit bisa direkomendasikan untuk mengurangi emesis gravidarum pada ibu hamil.

Maka dari itu peneliti ingin meneliti lebih lanjut tentang pengaruh mengkonsumsi pisang kepok (Musa paradisiaca formatypica) terhadap Penurunan Intensitas Mual Muntah Pada Ibu Hamil Trimester I di Wilayah Kerja Puskesmas Ingin Jaya tahun 2019.

\section{Metode}

Jenis penelitian ini adalah penelitian eksperimen (Intervensional) menggunakan model penelitian Eksperimen semu atau Quasi eksperimental dengan desain penelitian pre test and post test.

Intensitas mual muntah sebelum dilakukan intervensi pada kelompok pisang kepok, $x 1$ perlakuan pada kelompok pisang kepok, 02 Intensitas mual muntah sesudah diberikan intervensi pada kelompok pisang kepok. 03 intensitas mual muntah sebelum dilakukan intervensi pada kelompok vitamin B6, x2 perlakuan pada kelompok vitamin B6, 04 Intensitas mual muntah sesudah dilakakukan intervensi pada kelompok vitamin B6. 
Populasi dalam penelitian ini yaitu ibu hamil yang berada diPKM Ingin Jaya, ibu hamil trimester 1 yang mengalami mual muntah dengan pengampilan sampel menggunakan tehnik purposive sampling dengan menggunakan kriteria inklusi dan eklusi. Kriteria inklusi: Bersedia menjadi responden, mengalami mual muntah pada trimester I, bersedia tidak minum obat pada saat mengkonsumsi pisang. Sedangkan kriteria ekslusi: Tidak mengalami gangguan penyakit lainnya sehingga harus mengkonsumsi obat jenis lain.

Pengumpulan data dilakukan secara pengukuran langsung kepada subjek penelitian, serta proses wawancara menggunakan kuesioner. Data diolah melalui tahapan editing, koding, cleaning dan tabulating.

Analisis data dilakukan secara unvariat dan bivariat. Uji statistik yang digunakan pada analisis bivariat yaitu uji Dependent T-test dan Independent Ttest, dengan tingkat kemankaan $95 \%$.

\section{Hasil}

Penelitian tentang pengaruh pemberian pisang kepok (Musa paradisiaca formatypica) dalam menurunkan intensitas mual muntah Pada lbu Hamil Trimester I di Wilayah Kerja PKM ingin Jaya tahun 2019, telah dilaksanakan mulai bulan Juli sampai dengan bulan Oktober pada tahun 2019.

Jumlah responden dalam penelitian ini adalah 40 responden. Responden dibagi menjadi 2 kelompok yaitu 20 responden kelompok perlakuan pemberian pisang kepok (Musa paradisiaca formatypica) dan 20 responden dalam kelompok kontrol (pemberian vitamin B6).

Hasil penelitian secara deskriptif, didapatkan rata-rata mual dan muntah pada kelompok eksperimen sebelum pemberian pisang adalah 22.50 dimana berada pada kategori berat mengalami penurunan emesis saat post menjadi 15.50 berada pada kategori emesis sedang, sedangkan pada kelompok kontrol rata-rata mual dan muntah sebelum diberikan vitamin B6 adalah 18.20 berada pada kategori sedang mengalami penurunan emesis saat post menjadi 8.35 berada pada kategori ringan.dapat disimpulkan kedua kelompok setelah diberikan intervensi mengalami penurunan intensitas mual dan muntah.

Hasil penelitian menunjukkan bahwa secara signifikan terdapat pengaruh pemberian pisang kepok dan vitamin B6 dalam menurunkan intensitas emisis gravidarum pada ibu hamil $(p=$
0.000), selain itu dilaporkan juga bahwa terdapat perbedaan antara pemberian pisang kepok dengan pemberian Vitamin B6 terkait penurunan intensitas emisis gravidarum pada ibu hamil (nilai $p=0.045)$.

Hasil pengukuran terhadap variabel dependen dan independen yaitu pengaruh pemberian pisang kepok (Musa paradisiaca formatypica) dalam menurunkan intensitas mual muntah pada ibu hamil Trimester I di Wilayah Kerja Puskesmas Ingin Jaya tahun 2019.

\section{Pembahasan}

Berdasarkan hasil penelitian telah menunjukkan bahwa seluruh responden mengalami mual dan muntah baik pada kelompok eksperimen maupun kelompok kontrol. Runiari (2011), mengatakan bahwa mual muntah merupakan hal yang wajar dalam proses kehamilan namun bila tidak ditangani dengan baik akan berpotensial menjadi hiperemisis gravidarum yang dapat membawa masalah pada ibu dan bayi.

Penyebab yang pasti terjadinya emesis gravidarum tidak diketahui, namun beberapa faktor diantaranya Peningkatan hormon HCG, (estrogen dan progesteron) Faktor umur, gravida, pendidikan, pekerjaan (Kusmiyati, 2009). Penelitian ini dapat dilihat persentase kejadian emesis lebih banyak dialami oleh usia reproduktif (75\%), untuk pekerjaan lebih tinggi dialami oleh ibu yang tidak bekerja (80\%), sedangkan paritas lebih banyak responden yang multigravida.

Selanjutnya ditemukan dalam penelitian ini bahwa terdapat pengaruh pemberian pisang kepok dan tablet B6 terhadap emesis gravidarum yang dialami oleh ibu-ibu hamil, serta dengan konsumsi vitamin B6 dan Pisang kepok bisa membantu mengurangi rasa mual muntah, kandungan vitamin B6 pada pisang yaitu sebesar $0.5 \mathrm{mg} / 100$ gram. Untuk mengatasi rasa mual muntah saat kehamilan, dosis vitamin B6 yang diperlukan yaitu sebesar 10 mg untuk $3-4$ kali sehari.

Penelitian ini didukung oleh penelitian yang dilakukan oleh Rini \& Siti (2007), dengan temuannya bahwa pisang kepok yang telah direbus selama 40 menit terdapat kandungan B6 sebesar $0.36 \mathrm{mg} / \mathrm{g}$. Hasil penelitian ini juga sejalan dengan penelitian Nafisah (2015) yang menunjukkan adanya penurunan mual dan muntah sebelum dan sesudah intervensi dengan 
nilai $p=0,007$, simpulan terdapat pengaruh pisang ambon terhadap mual muntah selama kehamilan trimester I

Vitamin B6 (Piridoksin) memang merupakan salah satu cara farmakologis yang dapat digunakan untuk mengatasi mual dan muntah pada kehamilan, Suplementasi multivitamin secara bermakna mampu mengurangi kejadian mencegah insidensi hiperemisis gravidarum (Petik,dkk2005). Vitamin B6 merupakan koenzim yang berperan dalam metabolisme lipid, karbohidrat dan asam amino. Peranan vitamin B6 untuk mengatasi hiperemesis masih kontroversi. Dosis vitamin B6 yang cukup efektif berkisar12.5-25 mg per hari tiap 8 jam (Widayana et al., 2013). Selain itu Morgan et al. (2017), melaporkan suplementasi multivitamin secara bermakna dapat mengurangi kejadian mencegah insiden hyperemesis gravidarum.

\section{Kesimpulan}

Pemberian pisang kepok dan vitamin B6 berpengaruh dalam menurunkan intensitas emisis gravidarum pada ibu hamil, dan pisang kepok lebih efektif terhadap intensitas emisis gravidarum pada ibu hamil trimester I di Wilayah Kerja Puskesmas Ingin Jaya.

Saran, bagi ibu hamil untuk mengobati gejala mual dan muntah salah satunya mengkonsumsi pisang kepok dan mengurangi penggunaan obatobatan

\section{Ucapan Terima Kasih}

Ucapan terimakasih disampaikan kepada Direktur Politeknik Kesehatan Kemenkes Aceh yang telah membantu pendanaan terhadap pelaksanaan penelitian ini. Selain itu, ucapan terima kasih juga kami sampaikan kepada Ketua Jurusan Kebidanan dan Para Tim Pakar yang telah membantu perbaikan baik secara teknis maupun isi dalam pelaksanaan penelitian ini. Para Responden yang telah memberikan kesempatan dan membantu penulis dalam melakukan penelitian.

\section{Daftar Rujukan}

Andriani, E. (2012) Mencerdaskan Anak Sejak Dalam Kandungan. Jakarta: Kelompok Gramedia.
Aritonang, E. (2010). Kebutuhan Gizi Ibu Hamil. Medan: Kampus IPB Taman Kencana Bogor.

BKKBN (2003). Profil Kependudukan Indonesia. Diakses tanggal 25 Maret 2019

Ehiowermwenguan, G., Emoghene, $A$ and Inetianbor, J.E. Antibacterial and phytochemical analysis of Banana fruit peel. IOSR Journal of Pharmacy (e)-ISSN : 22503013,(p)-ISSN: 2319-4219, Volume 4,Issue 8 ( august 2019)PP.18-25

Elvika (2018). Efektivitas Pemberian Pisang Ambon dan Vitamin B6 untuk menurunkan Hiperemesis Gravidarum di BPM Endah Bekti, Jurnal Media Ilmu Kesehatan. Vol 7 no.1

Irianti, B., Halida, E. M., Duhita, F., Prabandari, Yulita, N., Hartiningtiyaswati, S., Aggraini, S. (2014). Asuhan Kehamilan Berbasis Bukti. Jakarta: Agung Seto.

Kusmiyati, Y. (2009). Perawatan Ibu Hamil asuhan ibu hamil. Yogjakarta: Fitramaya.

Lusiana (2017). Giving Effectiveness Against Decline Stew Ginger Nause Vomiting In Pregnancy Trimester I BPM Deliana2016, Jurnal Doppler Universitas Pahlawan Tuanku Tambusai, 1(2): $20-29$

Maulana, M. (2008). Penyakit Kehamilan dan Pengobatannya. Jogjakarta: Katahati.

Morgan, J. L., Kogutt, B. K., Meek, C., Wells, C. E., Stehel, E., \& Roberts, S. (2017). 903: Pharmacokinetics of amlodipine besylate during pregnancy-how much infant exposure occurs? American Journal of Obstetrics \& Gynecology, 216(1), S515-S516.

Petik D,Puho E,Czeizel AE,Evaluation of maternal infusion therapy during pregnancy for fetal development Int J Med Sci. Oct 2005;2(4):137-42

Ratih, R, H dan Qomariah, S (2017). Efektivitas Konsumsi Pisang Kepok Terhadap Emesis Gravidarum Pada Ibu Hamil Trimester I, Prosiding CEL Sci Tech UMRI, 2(2) 110-115

Rini, Siti, (2017). Kandungan vitamin B6 pada pisang kepok. Pekanbaru Riau. Jurnal Kesehatan Komunitas. 3(1) 10-14

Rohmah (2017). Pengaruh Konsumsi Pisang Ambon terhadap Penurunan Intensitas Mual Muntah pada Ibu Hamil Trimester 1 di Puskesmas Sukorame Kota Kediri

Siska (2015). Pengaruh aromaterapi Blended Peppermint dan Ginger oil terhadap rasa mual pada ibu hamil trimester satu di 
Puskesmas Rengel Kabupaten Tuban. diakses pada tanggal 25 Maret 2019

Suyanti (2008). Pisang. Jakarta: Penebar Swadaya

Widayana, A., Meghadana, I. W., \& Kemara, K. P.

(2013). Diagnosis Dan Penatalaksanaan Hiperemesis Gravidarum. E-Jurnal Med Udayana, 658-673.
Wiknjosastro, H. 2007. Ilmu Kebidanan. Jakarta : Yayasan Bina Pustaka Sarwono Prawirohardjo. 